\title{
Inviting Social Justice through Literacy: Creating a change using the critical questionings and using the language of power
}

\author{
Limor Pinhasi-Vittorio $^{1}$
}

This article converges on the importance of hearing all learners' voices in creating a just and safe learning environment. Following a critical pedagogy, the author stresses the importance of developing a line of critical questioning within the learners where the learners have the authority to query what they read as well as the world and not accepting things as face value. In addition, there is a focus on using the additive approach, whereby the language of power is taught in conjunction with vernacular language. Throughout the article there are examples of writings from two different marginalized groups illustrating the diversity and multiplicity of literacy while exhibiting critical thinking at its best. [Article copies available for a fee from The Transformative Studies Institute. E-mail address: journal@transformativestudies.org Website: http://www.transformativestudies.org (C2009 by The Transformative Studies Institute. All rights reserved.]

KEYWORDS: Critical Literacy, Social Justice, Additive Approach, Secondary Use of Language, Stranded English, Multiple Literacies.

\section{INTRODUCTION}

The article provides a short description of literacy in its critical sense, as a way to enact changes in one's life and as a self-empowering tool. The importance of acknowledging the diversity of learners is stressed and at the same time encouraging an "additive approach", where learners learn "the codes or rules for participating in power," in other words, the "cul-

\footnotetext{
${ }^{1}$ Limor Pinhasi-Vittorio, Ph.D., is an Assistant Professor of Literacy and the coordinator of the graduate program in Lehman College. Her work is focused on various marginalized groups and their literacy abilities. In her work she is using aesthetic education as away to promote critical literacy. Address correspondence to: Dr. Limor PinhasiVittorio, Lehman College, Department of Counseling, Leadership, Literacy and Special Education, Division of Education, Carman Hall B-20, 250 Bedford Park Blvd West, Bronx, NY 10468; e-mail: LIMOR.PINHASI-VITTORIO@lehman.cuny.edu.
} 